\section{Evaluation of Affinity of Neonicotinoid Insecticides for Rat Brain Nicotinic Acetylcholine Receptors by $\left[{ }^{3} \mathrm{H}\right]$ Epibatidine-Binding Assay}

\author{
Takashi OKUMOTO and Yoshihisa OzOE* \\ Department of Life Science and Biotechnology, Faculty of \\ Life and Environmental Science, Shimane University, \\ Matsue, Shimane 690-8504, Japan
}

(Received November 12, 2001; Accepted December 19, 2001)

Key words: neonicotinoid insecticide, nicotinic acetylcholine receptor, epibatidine, rat brain.

\section{INTRODUCTION}

Neonicotinoids are a novel class of insecticides that act as agonists for the nicotinic acetylcholine receptors (nAChRs) of insects. ${ }^{1)}$ The initial development of imidacloprid was soon followed by the production of several other neonicotinoids, and this class of insecticides continues to expand. In vivo tests have shown high insecticidal activity and low mammalian toxicity to be characteristics of these insecticides. It is of importance, however, to confirm that these insecticides do not act on the nAChRs of non-target animals in vitro. We here report the affinity of six neonicotinoids for rat brain nAChRs estimated by an assay using $\left[{ }^{3} \mathrm{H}\right]$ epibatidine (EPI), an agonist specific for $\alpha 4 \beta 2$-nAChRs, and show that this assay is both simple and useful for the above purpose.

\section{MATERIALS AND METHODS}

\section{Compounds}

The neonicotinoids were provided by Mitsui Chemicals, Inc. Tritiated $(1800 \mathrm{GBq} / \mathrm{mmol})$ and unlabeled $( \pm)$-EPI were purchased from NEN Life Science Products, Inc. and Sigma-Aldrich Co., respectively.

\section{Binding Assays}

Membranes containing nAChRs were prepared by the homogenization of rat brain in $1 \mathrm{mM}$ EDTA, followed by the centrifugation of the homogenate at $1000 \times \mathrm{g}$, the centrifugation of the supernatant at $25,000 \times g$, the dialysis of the resulting membrane fraction $(25,000 \times g$ pellets $)$ against distilled water, and the recentrifugation of the inner suspension at $25,000 \times g$, as described previously. ${ }^{2)}$ The final pellets were stored at $-80^{\circ} \mathrm{C}$ without significant loss of EPI-binding

\footnotetext{
* To whom correspondence should be addressed.

E-mail: ozoe-y@life.shimane-u.ac.jp
}

activity. Assays were performed by a filtration method in the usual manner. ${ }^{3)}$ In brief, the membranes $(200 \mu \mathrm{g}$ of protein) were incubated with $0.2 \mathrm{nM}\left[{ }^{3} \mathrm{H}\right] \mathrm{EPI}$ and the test compound in $200 \mu \mathrm{l}$ of $50 \mathrm{mM}$ Tris- $\mathrm{HCl}$ containing $120 \mathrm{mM}$ $\mathrm{NaCl}(\mathrm{pH} 7.4)$ at $37^{\circ} \mathrm{C}$ for $2 \mathrm{hr}$, unless otherwise noted. After the reaction was terminated by rapid filtration through $1 \%$ bovine serum albumin (BSA)-presoaked Whatman GF/C filters followed by washing with a buffer containing $0.2 \%$ BSA, ${ }^{4)}$ the membrane-bound radioactivity on the filters was measured using a liquid scintillation counter. Nonspecific binding was defined in the presence of $5 \mu \mathrm{M}$ unlabeled EPI. Compounds were first dissolved in dimethyl sulfoxide and then diluted with the buffer (final conc. $<0.1 \%$ ). Protein was determined using the Bradford method employing BSA as a standard.

\section{RESULTS AND DISCUSSION}

We performed binding assays on six compounds using $\left[{ }^{3} \mathrm{H}\right]$ EPI as a radioligand. EPI is a highly selective agonist for $\alpha 4 \beta 2$-nAChRs, ${ }^{5)}$ the predominant subtype in mammalian brain, and its tritiated form is superior to $\left[{ }^{3} \mathrm{H}\right]$ nicotine in terms of both selectivity and affinity. Prior to the neonicotinoid assays, conditions for the binding of $\left[{ }^{3} \mathrm{H}\right] \mathrm{EPI}$ to rat brain membranes were optimized. The $\left[{ }^{3} \mathrm{H}\right]$ EPI binding experiments were first conducted at 4,24 , and $37^{\circ} \mathrm{C}$. Little significant difference in the extent of binding was observed at the temperatures examined (Fig. 1A). Figure 1B shows the relation between $\left[{ }^{3} \mathrm{H}\right]$ EPI binding and the amount of membrane protein; the specific binding increased proportionally with an increase in the amount of protein up to 250 $\mu \mathrm{g}$, but tended to drop slightly at $500 \mu \mathrm{g}$ of protein. As for the time-course, the specific binding reached an equilibrium at 75 min (Fig. 1C). The apparent dissociation constant $\left(K_{\mathrm{d}}\right)$ and the maximal binding capacity $\left(B_{\max }\right)$ under the optimized conditions $\left(200 \mu \mathrm{g}\right.$ of protein, $2-\mathrm{hr}$ incubation at $\left.37^{\circ} \mathrm{C}\right)$ were estimated to be $186 \pm 9 \mathrm{pM}($ mean $\pm \mathrm{SD}, \mathrm{n}=3)$ and $186 \pm 36$ $\mathrm{fmol} / \mathrm{mg}$ of protein (mean $\pm \mathrm{SD}, \mathrm{n}=3$ ), respectively, by the analysis of the saturation isotherm of $\left[{ }^{3} \mathrm{H}\right]$ EPI binding (Fig. 1D).

The affinity of neonicotinoids for rat brain nAChRs was evaluated under the optimized $\left[{ }^{3} \mathrm{H}\right] \mathrm{EPI}$-binding conditions described above. Imidacloprid, acetamiprid, and clothianidin exhibited higher activity than did the other compounds; these three compounds at $10 \mu \mathrm{M}$ inhibited specific $\left[{ }^{3} \mathrm{H}\right]$ EPI binding by $60.6 \pm 2.3 \%, 56.3 \pm 1.6 \%$, and $33.6 \pm 8.0 \%$ (mean $\pm S D, n=4)$, respectively (Fig. 2). The other compounds, including the enantiomers of dinotefuran, had little inhibitory activity at $10 \mu \mathrm{M}$, indicating almost no significant interaction with $\alpha 4 \beta 2$-nAChRs in rat brain. Given that the $\mathrm{IC}_{50}$ values of imidacloprid and acetamiprid are approximately $10 \mu \mathrm{M}$, the $K_{\mathrm{i}}$ values, calculated according to the ChengPrusoff equation, ${ }^{6)}$ come to $c a$. $5 \mu \mathrm{M}$. Electrophysiological- 

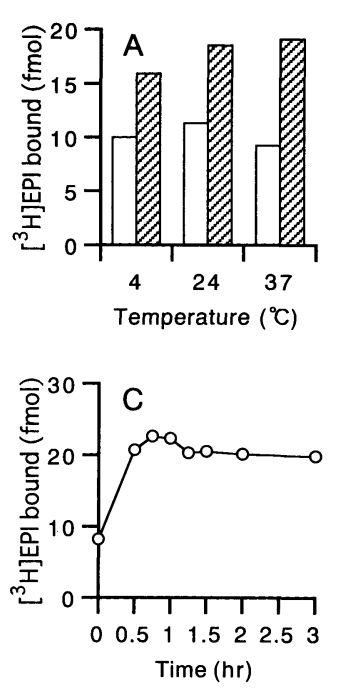

$70 \mu \mathrm{g}$

Q $140 \mu \mathrm{g}$
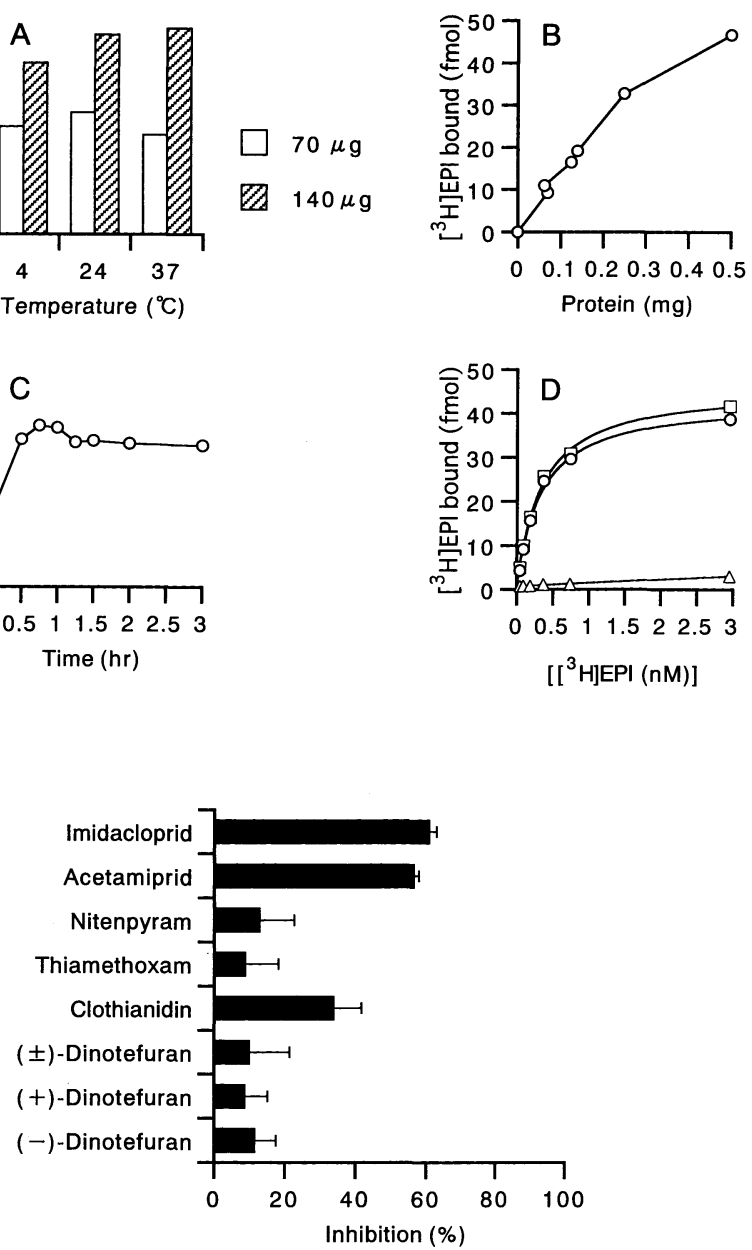

Fig. 2 Inhibition of $\left[{ }^{3} \mathrm{H}\right]$ EPI binding to rat brain membranes by neonicotinoids $(10 \mu \mathrm{M})$. Data are presented as the mean $\pm S D$ of four experiments, each performed in duplicate.

ly, imidacloprid was reported to be a partial agonist with an $\mathrm{EC}_{50}$ of $>79 \mu \mathrm{M}$ in chicken $\alpha 4 \beta 2$-nAChRs expressed in Xenopus oocytes. ${ }^{7)}$ The rank order in terms of activity in vitro of the tested compounds appears to be in general agreement with that of their acute oral toxicity in rats, ${ }^{8-10)}$ as well as that of their potency measured based on $\left[{ }^{3} \mathrm{H}\right]$ nicotine binding to rat recombinant $\alpha 4 \beta 2$-nAChRs. ${ }^{11)}$ Considering the range of nanomolar activity of these compounds in $\left[{ }^{3} \mathrm{H}\right]$ EPI assays using a cockroach nerve preparation, ${ }^{12)}$ the data presented here indicate that all tested compounds are highly selective for cockroach nAChRs versus rat $\alpha 4 \beta 2$-nAChRs.

\section{REFERENCES}

1) I. Yamamoto: "Nicotinoid Insecticides and the Nicotinic Acetylcholine Receptor," ed. by I. Yamamoto \& J. E. Casida, Springer, Tokyo, pp. 3-27, 1999

2) H. Hamano, K. Nagata, N. Fukada, H. Shimotahira, X.-L.
Fig. $1 \quad\left[{ }^{3} \mathrm{H}\right]$ EPI binding to rat brain membranes. (A) The temperature was varied. Other conditions were: $0.5 \mathrm{nM}\left[{ }^{3} \mathrm{H}\right] \mathrm{EPI} ; 2 \mathrm{hr} ; 70$ and $140 \mu \mathrm{g}$ of protein. (B) The amount of protein was varied. Other conditions were: $0.5 \mathrm{nM}\left[{ }^{3} \mathrm{H}\right] \mathrm{EPI} ; 37^{\circ} \mathrm{C} ; 2$ hr. (C) The incubation time was varied. Other conditions were: $0.5 \mathrm{nM}\left[{ }^{3} \mathrm{H}\right] \mathrm{EPI} ; 37^{\circ} \mathrm{C} ; 150 \mu \mathrm{g}$ of protein. (D) The concentration of $\left[{ }^{3} \mathrm{H}\right] \mathrm{EPI}$ was varied. Other conditions were: $37^{\circ} \mathrm{C} ; 2 \mathrm{hr} ; 200 \mu \mathrm{g}$ of protein. Each data point is the mean of duplicate determinations. The data are from a single experiment (A, B, and C) or from a representative experiment (D), which was repeated three times with similar results. $\triangle$ Nonspecific

- Specific
Ju \& Y. Ozoe: Bioorg. Med. Chem. 8, 665 (2000)

3) M. Qume: "Receptor Binding Techniques," ed. by M. Keen, Humana Press, Totowa, New Jersey, pp. 3-23, 1999

4) N. Orr, A. J. Shaffner \& G. B. Watson: Pestic. Biochem. Physiol. 58, 183 (1997)

5) V. Gerzanich, X. Peng, F. Wang, G. Wells, R. Anand, S. Fletcher \& J. Lindstrom: Mol. Pharmacol. 48, 774 (1995)

6) Y. Cheng \& W. H. Prusoff: Biochem. Pharmacol. 22, 3099 (1973)

7) K. Matsuda, S. D. Buckingham, J. C. Freeman, M. D. Squire, H. A. Baylis \& D. B. Sattelle: Br. J. Pharmacol. 123, 518 (1998)

8) I. Yamamoto: Agrochem. Jpn. 68, 14 (1996)

9) R. Senn, D. Hofer, T. Hoppe, M. Angst, P. Wyss, F. Brandl, P. Maienfisch, L. Zang \& S. White: Proceedings of Brighton Crop Protection Conference-Pests \& Diseases, pp. 27-36, 1998

10) K. Kodaka, K. Kinoshita, T. Wakita, E. Yamada, N. Kawahara \& N. Yasui: Proceedings of Brighton Crop Protection Conference-Pests \& Diseases, pp. 21-26, 1998

11) K. A. D’Amour \& J. E. Casida: Pestic. Biochem. Physiol. 64, 55 (1999)

12) K. Mori, T. Okumoto, N. Kawahara \& Y. Ozoe: Pest Manag. Sci. 58, 190 (2002)

\section{要 約}

$\left[{ }^{3} \mathbf{H}\right]$ エピバチジン結合阻害試験法によるネオニコチノ イド殺虫剈のラット脳ニコチン性アセチルコリン受容 体に対する親和性の評価

奥本剛司，尾添嘉久 $\alpha 4 \beta 2$ 二コチン性アセチルコリン受容体に選択性を示す $\left[{ }^{3} \mathrm{H}\right]$ エピバチジンを用いて, 最適化した条件下で結合阻害実験を行 い, ネオニコチノイド殺虫剂 6 種のラット脳ニコチン性アセチ ルコリン受容体に対する親和性を評価した。 イミダクロプリド が最も高い親和性を示し (10 $\mu \mathrm{M}$ で $60.6 \%$ の阻害), 次いでアセ トアミプリド，クロチアニジンの順となった. その他の 3 種に はほとんど親和性が認められなかった。 